\title{
New Original Images of the Macro and Microscopic Retina by Pixelometry of the Digital Optical Biopsy
}

Jorge Oscar Zarate*

Department of Pathology, University of Buenos Aires, New Zealand

Submission: December 01, 2019; Published: January 09, 2020

*Corresponding author: Mona Abdelkader, Department of Ophthalmology, University of Mansoura, Mansoura Ophthalmic Center, Egypt

Keywords: Pixelometric; Criteria; Tomography; Eucldiana; Geometric riemannian; Old fingerprint, Facial detectors; Face detection; Bar Codes

\section{Short Communication:}

In this work, we present some of the physical morphological results obtained from the sequencing of images with digital optical biopsy [1], using pixelometric and pixelographic criteria [2-4]. The cellular and tissue images, although they have a known pattern, show the difference of a pure, active image, captured by a tomography (OCT), or optical coherence tomography. The geometry of the pixels denotes a certain combination of eucldiana and two-dimensional elliptical, especially with options 3D allowed in the construction scheme geometric Riemannian, and the stocks of subpixels (red, green and blue) dead pixels and stuck, expressing where color and resolution monitors have reached almost improbable geometric expressions, graphics cards such as the S3, NVIDIA, or ATI among others., giving the opportunity to overcome infinitely genome combination possibilities of identification, in this case with 16.8 million colors (32 bits). The QRS, the old fingerprint, facial detectors FBT face detection, bar codes, different forms of interferometry and spectrometric, have led to the possibility of using non-invasive methods of protein identity uncalculated limits or the DNA (Figure 1-3).

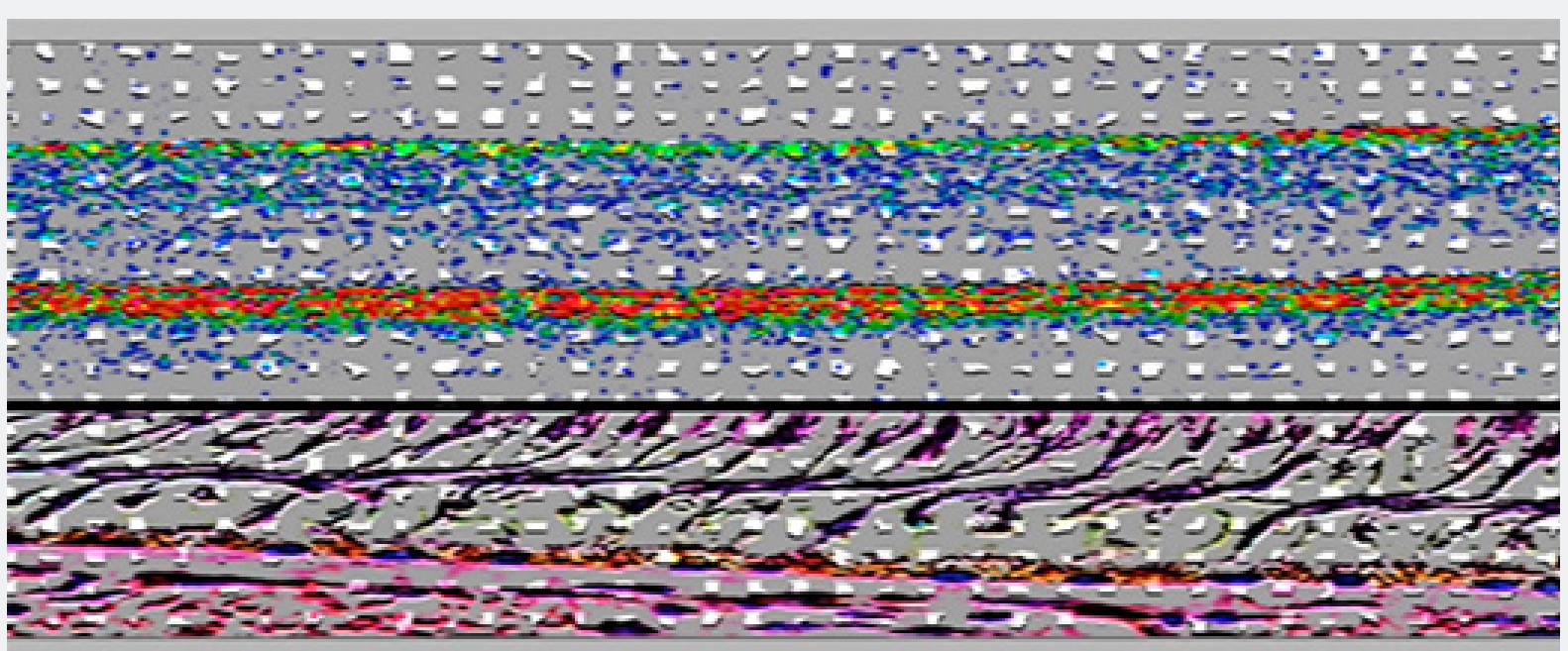

Figure 1: Pixelo-arquitectura of retinal tissue (original image of pixelografics retina). 


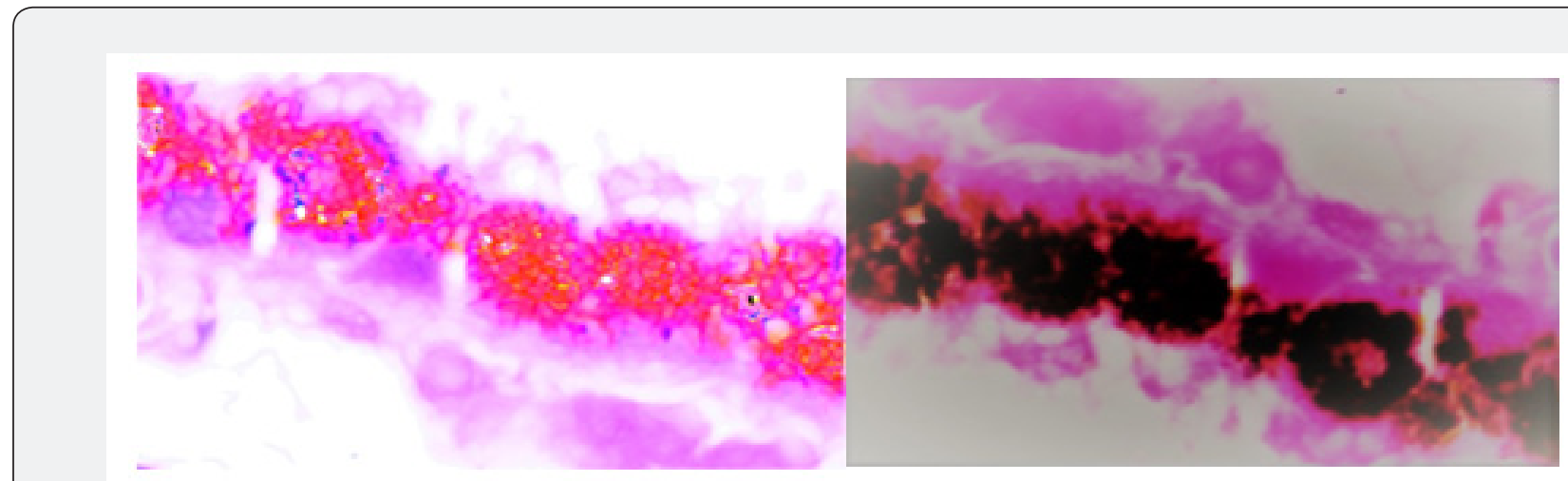

Figure 2: Pixeloarquitectural view of pigmentary epithelium of retina.

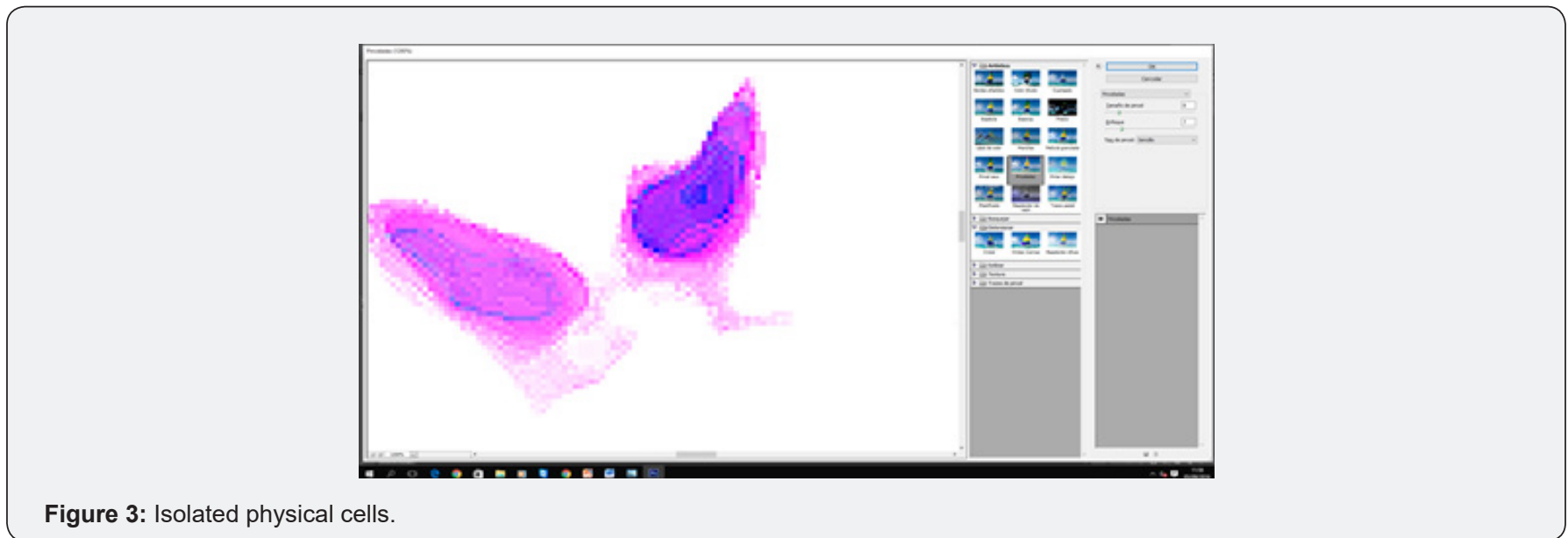

We used the pixelometric new non-Euclidean geometry described, about the pixel, as measurement converter, density, metric, shapes, etc. Information generates "every being-every particle, every force field, even the time-space continuum. "The smallest scale in the universe-the one governed by the laws of quantum physics-seems a challenge to common sense". Subatomic objects (pixel representation) can be in more than one place at a time, two particles at opposite ends of a galaxy can share information instantly, and the mere fact of observing a quantum phenomenon can radically change.

It we present some of the physical morphological results obtained from the sequencing of images with digital optical biopsy [5-8], using pixelometric and pixelographic criteria of the retina, and specially pigmentary epithelium. The cellular and tissue images, although they have a known pattern, show the difference of a pure, active image, captured by a tomography (OCT), or optical coherence tomography. The smallest scale in the universe-the one governed by the laws of quantum physics-seems a challenge to common sense. Subatomic objects (pixel representation) can be in more than one place at a time, two particles at opposite ends of a galaxy can share information instantly, and the mere fact of observing a quantum phenomenon can radically change it.

\section{References}

1. Wojtkowski M, Bajraszewski T, Gorczynska I, Targowski P, Kowalczyk A, et al. (2004) Ophthalmic imaging by spectral optical coherence tomography. Am J Ophthalmol 138(3): 412-419.

2. Zárate JO, Pelayes D, Singh A (2012) Optical digital biopsy. A new method of tissue and cell identification with ophthalmic applications. Patología 50(3): 179-181.

3. Zárate JO (2013) Optical Digital Biopsy. Brush strokes and pixels in the wonderful Latinamerican iconography. Patología 51(3): 206-209.

4. Zárate JO (2014) Digital optical biopsy. Possible extension to no other ophthalmic tissue. Patología Rev Latinoam 52: 246-247.

5. Zárate JO (2014) The pixelometría. New non-Euclidian geometry, biological importance. Patologia.

6. Zárate J O, et al. (2015) Optical Digital Biopsy: Uveal Choroidal Melanoma: Case Report and Update of Technology. Open Science Journal of Clinical Medicine 3(2): 59-63.

7. Zárate Jorge Oscar, Pelayes David, Folgar Martin, Lacarta Guillermo, Alvarado Miguel (2015) Optical Digital Biopsy: Subcellular Identification and Update of Technology. Open Science Journal of Bioscience and Bioengineering 2(2): 29-32.

8. Zarate JO, Racca ML (2008) Historia y Filosofia de la patología latinoamericana. Acuarelas micrográficas impresionistas de America Latina. Patologi 46(3): 295-296. 


\section{Your next submission with Juniper Publishers} will reach you the below assets

- Quality Editorial service

- Swift Peer Review

- Reprints availability

- E-prints Service

- Manuscript Podcast for convenient understanding

- Global attainment for your research

- Manuscript accessibility in different formats

( Pdf, E-pub, Full Text, Audio)

- Unceasing customer service

Track the below URL for one-step submission https://juniperpublishers.com/online-submission.php 